\title{
Perempuan dalam Masyarakat Papua: Suku Kamoro dan Muyu
}

\author{
Antie Solaiman \\ Universitas Kristen Indonesia, Jakarta
}

\begin{abstract}
Abstrak: Tulisan ini menilik dua jenis komunitas suku, Kamoro dan Muyu, atau dua 'warna' perempuan yang penulis anggap dapat mewakili keseluruhan perempuan Papua. Penulis beberapa kali mengunjungi Papua dalam satu dekade terakhir, pada kesempatan tersebut penulis tinggal dan beraktivitas bersama masyarakat Kamoro dan Muyu. Kedua komunitas tersebut tinggal di tanah Papua, yang secara administratif ada di Provinsi Papua Barat dan Provinsi Papua. Dengan melihat kepada kondisi dan konteks sosial-budaya yang melatari posisi perempuan Papua di tengah masyarakatnya, penulis ingin memberikan penggambaran yang jelas bagaimana sesungguhnya kesulitan yang dialami perempuan Papua sebagai warga negara.
\end{abstract}

Kata Kunci: Perempuan, Papua, Kamoro, Muyu

Abstract: This article looks at two ethnic communities, Kamoro and Muyu, or two 'colours' of women whom the writer considers as representative of all Papuan women. The author has several times visited Papua in the past decade, on that occasion the author lived and did activities together with the Kamoro and Muyu people. Both communities live in the land of Papua, which administratively are in the West Papua and Papua Provinces. By looking at the condition and socio-cultural context which underlie the position of women in the midst of their society, the author wants to give a clear description on how difficult it is the real situation faced by Papuan women as citizens.

Key Words: Papua, Women, Kamoro, Muyu

Korespondensi Penulis:

Antie Solaiman, Pusat Studi Papua, Universitas Kristen Indonesia.

E-mail: antie0912@gmail.com 


\section{Pendahuluan: Kedaulatan Negara dalam Kewarganegaraan}

Dalam paham yang kita terima, 'kedaulatan negara' adalah kekuasaan mutlak atau tertinggi yang dimiliki negara atas penduduk dan wilayah bumi beserta isinya yang dipunyai oleh suatu sistem negara yang berdaulat. Sifat kekuasaan ini: memaksa. Artinya, negara punya sifat memaksa; memiliki kekuatan fisik secara legal, monopoli. Negara mempunyai sifat monopoli dalam menetapkan tujuan bersama masyarakat dan sifat tersebut mencakup semua (all-embracing). Semua peraturan perundang-undangan yang berlaku adalah untuk semua orang tanpa kecuali. Kata 'daulat' dalam pemerintahan berasal dari kata daulat (Arab), supremus (Latin), sovereignity (Inggris), souvereiniteit (Prancis), dan sovranita (Italia) yang berarti "kekuasaan tertinggi”.

Kedaulatan negara dalam arti kenegaraan adalah kekuasaan penuh dan tertinggi dalam suatu negara untuk mengatur seluruh wilayahnya tanpa campur tangan negara lain. Jean Bodin pernah mengatakan kedaulatan negara, sama dengan atribut dan ciri khusus negara yang tunduk pada hukum internasional, tidak boleh melanggar atau merugikan kedaulatan negara lain. Dengan demikian, kedaulatan negara adalah asli, permanen, tunggal, dan absolut. Hak berdaulat negara umumnya mengatur pemanfaatan sumber daya alam.

Sementara, keanggotaan seseorang dalam kontrol satu politik tertentu (secara ke luar adalah 'negara') membawa hak untuk berpartisipasi dalam kegiatan politik. Seseorang dengan keanggotaan yang demikian disebut 'warga negara'. Status seorang warga negara haruslah tinggal dan berpartisipasi dalam suatu negara yang diakui oleh Undang-Undang atau peraturan yang berlaku di negara tersebut.

Penulis memilih 2 (dua) jenis komunitas suku atau 2 (dua) 'warna' perempuan yang penulis anggap bisa mewakili keseluruhan perempuan Papua yang tinggal di wilayah Papua, yang secara administratif ada di wilayah Provinsi Papua Barat dan 
Provinsi Papua. Dalam administrasi adat, mestinya ada 7 (tujuh) jenis perempuan yang harus diungkapkan dalam teks ini. Tetapi, karena keterbatasan yang ada, maka penulis hanya menampilkan dua perwakilan komunitas saja.

\section{Perempuan Kamoro}

\section{Geografi dan Lingkungan}

Dalam sejarah disebutkan bahwa di daerah Mimika, gereja sudah dibangun sejak tahun 1928. Gereja Katolik bertumbuh bersama Gereja Protestan. Pada tahun 1940, umat makin bertumbuh. Tetapi kemudian tentara Jepang masuk ke Teluk Etna. Para pastor dan pendeta melarikan diri ke Merauke, bahkan terbang mengungsi ke Australia (Duivenvoorde 2000, 94). Rakyat Mimika menderita parah dijajah Jepang. Juga kehidupan gereja menjadi sangat merosot. Baru pada bulan Mei 1946, setelah Jepang menyerah dan Indonesia merdeka, para misionaris kembali masuk.

Pendidikan persekolahan sudah terlantar selama lima tahun. Wilayah Kokonao mulai dibangun sebagai 'pusat'. Semua diperbaiki sejak tahun 1948 - 1952. Kokonao mendapatkan bantuan istimewa dari para suster pada tahun 1949. Suster membuka asrama untuk para gadis Kamoro dan memulai poliklinik. Pada masa ini sebuah lembaga pelayanan The Evangelical Alliance Ministry (TEAM) dari Amerika datang melayani di Agats, Kabupaten Asmat sekarang ini.

Dari penjelasan di atas, dapat dilihat bahwa pemerintahan di Mimika sebetulnya dimulai oleh kaum misionaris. Masyarakat lokal sebelumnya adalah masyarakat hutan yang tidak mengenal lapisan-lapisan sosial-masyarakat Papua adalah masyarakat yang sangat egaliter. Pemerintahan tradisional hanya mengenal masyarakat dan kepala suku, keduanya saling berhadapan; rakyat tunduk kepada apa yang dikatakan oleh kepala suku. Di bagian selanjutnya, penulis akan mendeskripsikan situasi perempuan Kamoro. Secara 
khusus, tulisan penulis terbatas pada mereka yang tinggal di 'kota kecil' Kokonao. Hal ini dipilih untuk mempersempit ruang analisis, mengingat wilayah di mana suku Kamoro tinggal adalah cukup luas.

Kokonao terletak di bagian selatan dari Kabupaten Mimika yang beribukota di Timika. Pada waktu itu penambangan emas di Freeport belum dimulai, baru dilakukan penelitian-penelitian. Penulis memilih kota kecil Kokonao untuk di-post di sini karena tempat ini merepresentasikan suku Kamoro. Sementara Timika tidak dipilih karena sudah merupakan kota urban, di mana banyak imigran datang, bercampur aduk - Jawa, Bugis, Buton, Makassar, selain berbagai suku Papua lainnya - sehingga tidak lagi mewakili penduduk asli di wilayah ini, baik suku Amungme maupun suku Kamoro.

Di Kokonao terdapat mitologi mengenai asal-muasal nama 'Kokonao'. Kokonao berasal dari kata Kaokandau. Kaoka berarti "perempuan" dan Ndau berarti "dibunuh". Dalam mitologi setempat, dikisahkan bahwa ada sekelompok perempuan sedang "mencari" ${ }^{1}$ di sungai dekat delta Sungai Kokonao. Saat itu masih terdapat perang Hongihongi. Perempuan-perempuan tersebut akhirnya dibunuh. Sejak itulah nama tempat itu dikenal sebagai Kaokandau atau Kokonao sesuai dengan sejarah yang terjadi di tempat itu. Seorang informan, Mama Beyata di Kampung Migiwia, mengatakan bahwa penyusunan nama Kamoro sangat terpengaruh dengan kehadiran lembaga adat.

Mama Beyata bertutur bahwa Lembaga Masyarakat Adat Suku Kamoro (Lemasko) dan Lembaga Pengembangan Masyarakat Amungme dan Kamoro (LPMAK) dalam berdiskusi mengenai penamaan Suku Kamoro tidak melibatkan para orang tua; mereka hanya menanyakan pendapat kaum muda, sehingga tidak bisa mendapatkan cerita 'yang benar'. Mereka berkomunikasi hanya dengan anak-anak muda, yakni anak-anak muda

1 "Mencari" adalah kata lain dari "mengumpulkan bahan pangan". 
yang baru saja jadi pegawai. Kalau waktu itu mereka bertanya kepada kelompok orang tua, pasti mereka akan pakai nama "Mumuika”, jelas Mama Beyata.

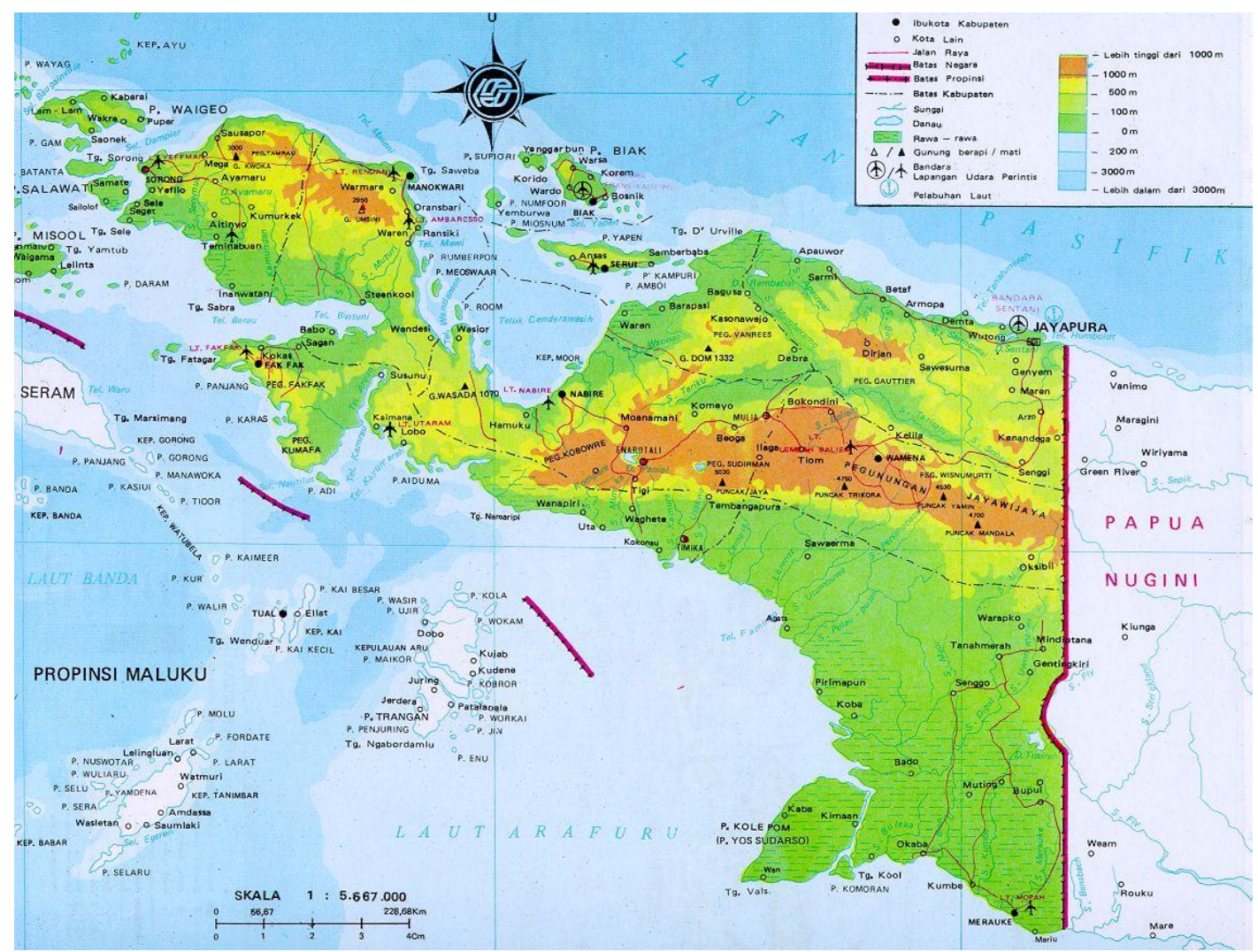

Sumber: World Team Papua 2009

Gambar 1. Peta Papua

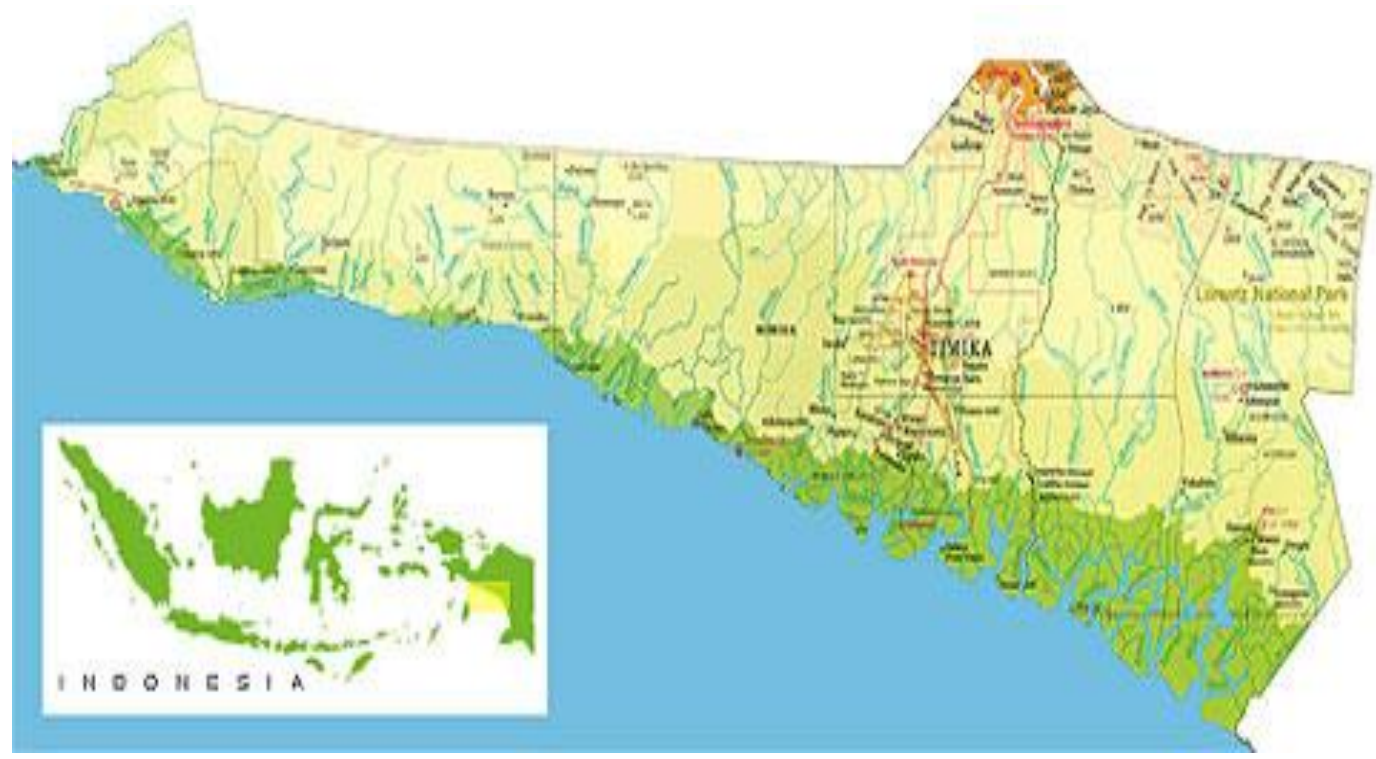

Sumber: Pemda Kabupaten Mimika tanpa tanggal

\section{Gambar 2. Peta Kabupaten Mimika}


Dalam tulisan Pouwer (2010), orang Kamoro lebih dikenal dengan nama Mimikans. Nama Kamoro diperkenalkan pertama kali oleh Pater Petrus Drabbe M. S. C. Kamoro berarti "orang yang hidup", sebagai lawan dari "roh" (orang yang sudah mati). Nama tersebut diberikan karena tidak ada bahasa asli yang digunakan untuk menamai kelompok suku ini. Orang-orang di luar menyebut mereka sebagai "we nata" yang artinya "manusia yang sesungguhnya".

\section{Hidup Sehari-hari}

Saat penulis bicara soal pasang-surut air sungai, penulis mendengar jawaban bahwa di siang hari saat air pasang, juga merupakan waktu buat sebagian warga pulang setelah mencari makanan di kepala air. Menurut orang-orang Kamoro, pada saat air pasang itulah masyarakat setempat pulang dari kepala air, sebutan untuk daerah yang sangat subur di mana seluruh bahan makanan yang mereka butuhkan tersedia. Termasuk di sini adalah sagu yang adalah makanan pokok orang-orang di Kokonao.

Penulis memperhatikan alam ber-rawa-rawa sungai itu membentang luas. Di sanalah masyarakat mencari makanan lainnya, seperti karaka dan berbagai jenis ikan, seperti ikan kakap putih atau ikan baramundi, serta berbagai jenis siput. Berlimpahnya sumberdaya hayati di tempat ini rupanya tidak menjamin kesejahteraan bagi masyarakat setempat. Jaminan kesehatan dan pendidikan yang masih sangat terbatas membuat mereka hidup dalam jurang kegelapan yang masih jauh sekali dari makna modern yang selama ini dirasakan orang secara umum.

Pertumbuhan penduduk cukup tinggi di Kokonao. Dari pengamatan penulis cukup banyak anak-anak dan remaja di tempat ini. ${ }^{2}$ Anak-anak cenderung berlarian ke sana ke

\footnotetext{
2 Penulis mengunjungi wilayah ini empat kali: pada tahun 1997, 2001, 2011, dan terakhir tahun 2014.
} 
mari: ada yang bermain bola di lapangan, ada yang berlarian di sekitar halaman rumah, ada juga yang sekedar duduk-duduk sambil mengobrol di warung. Tak jauh dari dermaga, terdapat sebuah rumah tempat usaha pengolahan kayu. Beragam jenis kayu dikirimkan ke sini untuk digunakan bagi pembangunan Rumah Sakit di dekat asrama, dengan menggunakan satu-satunya mobil yang ada di kota sepi ini.

Orang Kamoro dalam pengamatan penulis merupakan sisa-sisa masyarakat pemburu dan peramu. Mereka mengumpulkan bahan makanan dari hutan di kepala air dan juga di sungai-sungai sekitar tempat tinggal mereka. Sagu dan babi mereka peroleh dari hutan di daerah kepala air. Untuk ikan dan berbagai jenis siput mereka mencarinya di muara-muara sungai. Tidak hanya mengurus keluarga dan membesarkan anak, namun juga aktivitas ekonomi orang Kamoro sebagian besar (atau secara umum) adalah tanggung jawab perempuan.

Perempuan memegang peran cukup dominan dalam tugas memproduksi makanan. Mereka bertanggung-jawab dalam hal menanam, mengumpulkan sagu, mencari ikan, berbagai jenis kerang, dan juga bertanggung-jawab pada kegiatan yang lebih luas lagi, yakni membuat dan menyiapkan kebun. Dalam kegiatan ini bukan berarti laki-laki tidak berkontribusi sama sekali. Laki-laki memang ada juga membantu perempuan mengumpulkan makanan, khususnya dengan cara memancing atau menjaring ikan. Namun peran laki-laki dalam hal mencari makanan tidak dilakukan sebagai rutinitas sehari-hari. Peranan laki-laki hanyalah sebagai dukungan terhadap kegiatan atau kewajiban perempuan mencari makan. Jadi, memelihara keluarga dengan mencukupi makanan adalah tugas perempuan setiap hari.

Kegiatan mencari makan dilakukan oleh kaum perempuan Kamoro dengan rajin dan seksama, penuh tanggung-jawab. Mereka mencari tambelo, sejenis molusca yang menjadi andalan dalam mendapatkan protein bagi keluarga. Berbarengan kaum 
perempuan mencari bahan makanan. Kegiatan mengumpulkan bahan makanan ini mereka sebut sebagai kegiatan "mencari" di pagi hari. Biasanya mereka sudah lebih dulu menyiapkan makanan dari bahan sagu seperti sinoli - sagu yang dihancurkan menjadi tepung dan dimasak di atas kuali dengan sedikit campuran santan atau air kelapa.

Selain sagu sinoli, makanan lain yang terbuat dari sagu adalah sagu bola dan sagu tindis. Sagu bola adalah sagu yang dihancurkan terlebih dahulu, lalu diberi air dan dibentuk menjadi bulat, lalu dibakar di atas api. Untuk memakannya, bagian terluar dari bola sagu yang sudah masak dikuliti, sisa sagu yang masih berbentuk bola itu masih dapat dibakar untuk kembali diambil kulit terluarnya. Sementara itu, sagu tindis adalah olahan selanjutnya dari sagu sinoli yang telah masak, tapi kemudian dipadatkan di atas kuali. Setelah padat, sagu tindis dimasak hingga mengeras di atas kuali.

Makanan-makanan ini mereka masak sebagai sebagai bahan makanan yang akan mereka makan, sebelum pergi ke hutan. Makanan-makanan ini juga merupakan persediaan pangan di rumah bagi anak-anak mereka yang tidak ikut ke hutan, atau juga bagi kaum laki-laki yang tinggal di rumah. Setelah sarapan, kaum mama atau para ibu ini pergi ke hutan. Saat berangkat, biasanya mereka mengajak anggota keluarga atau kerabat yang tinggal di sekitar rumah untuk ikut "mencari". Saat mengikuti para perempuan mencari tambelo, seorang ibu secara natural menjadi orang yang dituakan di kelompok itu. Seorang $\mathrm{ibu}^{3}$ berteriak di depan rumah sesaat sebelum berangkat, memberitahukan bahwa ia akan mencari tambelo ke hutan. Tak lama kemudian bersama beberapa perempuan, penulis mengikutinya menuju hutan.

Kami menuju ke hutan mencari tambelo. Hutan tersebut di seberang Timika Pantai Alo. Seorang lelaki mengantar kami dengan perahu misionaris. Saat itu sungai sudah

\footnotetext{
3 Dalam tulisan selanjutnya, penulis akan menggunakan istilah 'mama' untuk menyebut 'ibu' sebagaimana masyarakat lokal menyebutnya.
} 
pasang, namun permukaan belum terlalu tinggi. Perahu mengantar kami ke tepi hutan bakau. Penulis memasang sepatu boot. Sepatu perlu karena saat melangkah masuk ke hutan, mama pemimpin menjelaskan bahwa akar-akar bakau akan menyakiti kaki.

Ketika kaki melangkah masuk ke dalam lumpur di pinggir hutan bakau, benar saja; meski sudah menggunakan sepatu boot, lumpur terlalu dalam sehingga membuat air dan sebagaian lumpur masuk ke dalam sepatu dan mengotori celana dan kaki penulis. Dua orang mama membantu penulis berjalan ke luar dari lumpur. Di dalam hutan bakau, seorang mama berhenti di dekat sebuah batang pohon bakau yang sudah tumbang. Batang bakau itu berdiameter sekitar 20-an cm. Segera seorang mama mengeluarkan kapak yang ia bawa, lalu langsung membelah batang itu. Awalnya, karena batang bakau sudah tumbang dan terendam air, penulis pikir batang itu tidak keras; ternyata dugaan penulis salah.

Saat mama tadi membelah batang pohon bakau, terdengar suara dentuman sangat keras, yang cukup memekakkan telinga penulis. Suara itu menandakan bahwa kayu yang dibelah sangatlah keras. Mama Maria, yang memimpin kami, tak membantu mama pertama tadi yang sedang membelah batang pohon; tapi ketika pohon sudah terbelah, nampaklah gumpalan-gumpalan putih. Itulah yang dimaksud dengan tambelo. Mama Maria langsung mengambili molusca yang mirip cacing-cacing putih berukuran 20 -an cm yang ada di tengah-tengah belahan pohon itu. Kami mengambil tambelo itu, lalu menelannya begitu saja. Rasanya memang sama seperti kerang yang biasa kita santap di meja-meja restoran Jakarta.

Mama pemimpin tadi menjelaskan bahwa batang pohon itu tidak banyak menyediakan tambelo. Kami lalu berpindah menuju hutan di bagian dalam. Kaum perempuan dalam rombongan lalu memisahkan diri. Mereka yang duluan masuk ke hutan mencari karaka alias kepiting. Dua mama yang bersama penulis mengajak pindah 
untuk mencari batang pohon yang lain. Mama pemimpin membelah batang pohon yang berdiameter sekitar 50 -an $\mathrm{cm}$. Batang besar langsung terbelah dengan jumlah tambelo yang melimpah di dalamnya. Semua mama itu, langsung memasukkannya ke dalam mulut mereka. Sebagian dikumpulkan untuk misionaris pemilik perahu.

Mengikuti para mama ini mencari tambelo, penulis merasakan betapa beratnya beban kaum perempuan Kamoro! Bukan hanya lumpur yang menghadang mereka, tapi keseluruhan aktivitas mengumpulkan pangan buat keluarga sungguh pekerjaan berat. Menokok sagu, menangkap dan mengikat karaka, mengapak pohon, sungguh membutuhkan tenaga ekstra: seolah melebihi kekuatan perempuan. Selain itu, buaya dan ular masih banyak ditemukan di dalam hutan berair itu.

Mengumpulkan makanan bukanlah perkara mudah di Papua. Kendati segala jenis keragaman hayati tersedia di wilayah itu, tapi memperolehnya adalah perjuangan, tidak bisa dilakukan sendirian. Perlu diingat bahwa kondisi geografis di wilayah pesisir Timika bukanlah wilayah yang mudah untuk dijelajahi. Sebagian besar wilayah ini penuh ditumbuhi pohon bakau. Bila kita bergerak naik menuju kepala air, vegetasi di hutan semakin rimbun ditumbuhi oleh berbagai jenis tanaman, salah satunya sagu. Untuk mencari makanan mereka sehari-hari mereka sangat bergantung pada pasang-surutnya air sungai.

Seperti disinggung di awal, masyarakat Kamoro adalah sisa-sisa masyarakat pemburu dan peramu. Maka sebagian besar kegiatan ekonomi mereka, bersandar pada kegiatan subsisten saja. Artinya, mekanisme penyimpanan bahan makanan hanya diterapkan pada makanan pokok seperti sagu, dan beras bila jika mereka dapat membeli beras. Untuk makanan pendukung seperti udang, ikan, kepiting dan siput dikumpulkan setiap hari. Akan tetapi, selain mengumpulkan makanan setiap hari, masyarakat Kamoro 
juga bergantung pada pendapatan yang berasal dari penjualan kayu ukiran, dan hasil penjualan ikan.

\section{Pendidikan dan Kesehatan}

Banyak orang berpikir bahwa Kokonao itu sama dengan Timika, dalam arti kemajuannya. Kenyataannya, tidak. Timika adalah kota di mana orang-orang asli Papua sudah bukan mayoritas. Timika penuh dengan imigran, yang datang dari banyak tempat; antara lain Bugis, Buton, Makassar, Toraja, Batak, Manado, dan warga Papua lain yang bukan dari suku Amungme dan Kamoro. Mereka datang untuk bekerja. Timika adalah kota terdekat buat Kuala Kencana dan Tembagapura, dua kota 'buatan' perusahaan tambang kondang, PT Freeport. Kedua kota yang disebut terakhir ini adalah kota yang menjadi tempat berkumpul dan tinggalnya pegawai-pegawai Freeport. Imigran dari luar yang masuk ke Timika selain para pegawai Freeport dan keluarga, adalah juga para pencari kerja di beberapa perusahaan sub-kontrak Freeport, juga kaum pedagang yang membuka toko, restoran, dan berbagai jasa seperti menjadi sopir angkot, usaha foto studio, event organizer untuk pesta pernikahan, dan lain-lain.

\section{- Pendidikan: Suka-Duka Guru}

Kokonao mendapat julukan "Kota Tua”. Di gerbang Bandara Apuriyu tertulis nama itu, "Kota Tua"; juga di prasasti peresmian lapangan sepak bola Kokonao yang ditandatangani oleh Freddy Numberi, dan pada Tugu Selamat Datang di Dermaga Utama. Kokonao dibangun pada tahun 1927 oleh misionaris gereja Katolik dari Belanda. Pastor Le Cocq D’Armandville-lah yang mendirikan gereja, sekolah dasar (SD), asrama, dan rumah sakit. Dua tahun sebelumnya, pemerintah Belanda sudah hadir di sana. Sedangkan Timika dibangun pada tahun 1967. 
Di zaman itu, Kokonao menjadi pusat pendidikan bagi masyarakat suku Kamoro. Misionaris mendatangkan guru-guru dari Kei untuk mengajar di kampung-kampung. Sebagian pemuda Kamoro dikirim ke Merauke untuk meneruskan pendidikan menjadi guru. Beberapa dilatih menjadi tukang kayu; dan kaum perempuan dididik menjadi bidan dan perawat (Bentara Budaya, Freeport dan Papua Center UI 2012).

Suster-suster dari Hati Kudus (MSC) datang melatih remaja perempuan agar memiliki keterampilan. Mereka dimasukkan asrama, sekolah di Sekolah Kepandaian Putri (SKP) di mana kurikulumnya mengajarkan antara lain memasak dan menjahit. Sampai dengan akhir tahun 1968, sekolah itu masih ramai dan favorit. Masuk ke zaman Orde Baru, sekolah mulai merorot, dan kini tiggal kenangan.

Pada Perang Pasifik, di wilayah Kokonao, persisnya di Kampung Keakwa Lama, militer Jepang membangun pangkalannya. Pesawat-pesawat tempur Jepang meluncur berseliweran menahan serangan Sekutu yang berbasis di Hollandia-sekarang Jayapura. Dua moncong meriamnya berjaga mengarah ke Laut Arafura guna menghadang laju armada Sekutu.

Di Keakwa Baru berdiri sebuah gedung SD yang nyaris roboh. Atap sudah menganga, dinding rontok, dan ruang-ruang kelas sudah kosong-tak berbangku, tak bermeja, dan tak nampak lagi papan tulis. Rumput di halaman sudah meninggi dan liar. Satu-satunya penanda bahwa gedung ini bangunan sekolah adalah papan nama yang masih tegak kokoh dan tiang bendera yang dipatok dengan besi dan semen.

Sekolah ini memang menjadi tonggak sedih dunia pendidikan di Keakwa Baru. Guru dan murid meninggalkan sekolah itu. Segelintir guru mencoba bertahan di belantara. Anak-anak tinggal beberapa juga. Di tempat ini tidak ada penerangan listrik. Air bersih-termasuk air minum-mengandalkan hujan. Tidak ada jaringan komunikasi ke luar kampung. Hal yang paling berat: malaria menjadi musuh yang nyata. Selain itu, guru 
juga hidup terpisah dari keluarga, antara lain karena fasilitas yang minim di kota ini. Kebanyakan guru meninggalkan tempat tugas untuk waktu yang lama. Bahkan ada yang tidak pernah muncul sampai bertahun-tahun. Yang bertahan umumnya adalah guru "Kontrak"; mereka itu menerima gaji di tempat tugas, yakni di Kampung Keakwa Baru ini. Sementara itu, para Pegawai Negeri Sipil (PNS) menerima gaji di kota Kokonao. Kontrak guru dibuat untuk dua tahun. Kontrak ini yang membuat para guru kontrak bertahan sampai masa perjanjian itu usai. Transportasi dari kampung ke kota tidaklah murah dan tidak mudah.

Disebutkan bahwa awal tahun bisa jadi 30-an anak masuk mendaftar. Tapi seiring dengan berjalannya waktu, jumlah itu akan menyusut; kelas makin sepi. Pada akhir kelas VI, jumlah murid jadi bisa dihitung dengan jari tangan. Banyak murid meninggalkan sekolah begitu saja-tidak ada alasan jelas. Ada yang mengikuti orang tuanya ke pelabuhan untuk menjadi kuli bongkar muat di Poumako. Yang lain lagi mengikuti kebiasaan keluarganya, pergi mencari sagu ke kepala air selama satu sampai dua minggu. Ketika kembali ke kampung, semangat belajar sudah hilang. Ujian SD rata-rata diikuti oleh 5-6 orang saja. Ada juga yang meninggalkan sekolah karena hamil, sebab anak-anak Kamoro sudah aktif secara seksual pada usia 15-16 tahun. Ini berlaku bagi laki-laki dan perempuan. 


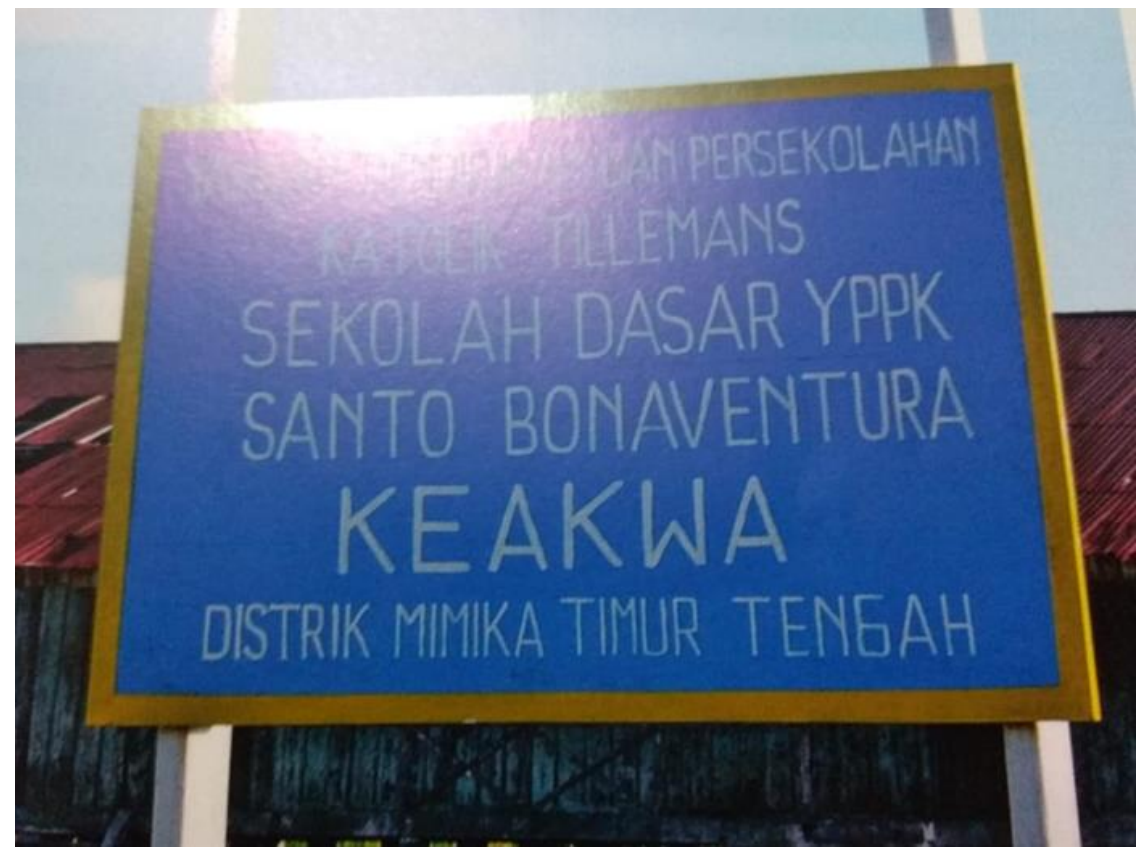

Sumber: Dokumentasi pribadi 2007

\section{Gambar 3. Papan Nama Sekolah Dasar di Keakwa Baru}

Semangat 'pergi sekolah' atau 'belajar' adalah hal yang mahal di Keakwa, Kokonao. Atau juga di Atuka, desa sebelahnya. Sampai kelas III atau IV, anak-anak belum juga bisa membaca. Mereka hanya belajar baca-tulis satu hingga dua jam, sesudah itu bermain. Tak pernah ada Pekerjaan Rumah atau 'PR' seperti anak-anak lain di Jawa atau di kota-kota lain. Juga di kampung ini tak ada tantangan sama sekali untuk mahir membaca. TV jarang ada, koran tidak ada. Yang ada adalah mencari kepiting, menokok sagu, atau mencari rezeki di pelabuhan.

- Kesehatan

Masalah kesehatan menjadi beban yang berat bagi masyarakat Kamoro. Tuberculosis (TBC) dan malaria adalah pasangan penyakit yang tak asing bagi warga. Hampir semua pernah terjangkit oleh dua penyakit ini. Sesudah dewasa, datang lagi penyakit yang lain: HIV/AIDS. Pengetahuan yang rendah tentang risiko-risiko penyakit tersebut menjadi penyebab nyawa mereka mudah sekali 'terbang'. 
Dokter Enny Kenangalem ${ }^{4}$ menuturkan bahwa tingkat kesehatan masyarakat Amungme dan Kamoro sangat rendah. Selain pengetahuan yang sangat kurang tentang kesehatan, masyarakat juga berhadapan secara langsung dengan ancaman bahaya penyakit. Nyamuk yang ada di mana-mana, sulitnya akses air bersih, dan tenaga kesehatan yang terbatas, membuat kesehatan masyarakat dalam posisi menyedihkan. Pelayanan pemerintah di bidang kesehatan dirasakan kurang sungguh-sungguh. Dokter Enny merasa bahwa wilayah Mimika selalu sesak dengan masalah politik, sedangkan kehidupan yang sehat tidak terlalu dipikirkan.

\section{Perempuan Muyu}

\section{Geografi dan Lingkungan}

Penulis berkontak cukup lama, selama lebih dari enam tahun sejak tahun 2005 dengan kaum perempuan asal suku Muyu. Tetapi kontak ini terjadi tidak secara khusus di wilayah Muyu an sich, melainkan di banyak kesempatan kunjungan. Perempuan Muyu banyak kita temui di Merauke-kota Merauke dan seluruh Kabupaten Merauke-seperti di Semangga, Kurik, dan kompleks Mangga Dua, juga Bupul dan Jagebob, serta Wasur. Akan tetapi, pada tahun 2012-2014, penulis berkesempatan kontak cukup intens dengan perempuan Muyu. Penulis menyusuri desa-desa, mulai dari Kurik, Kuprik, Jagebob, terus naik menyusuri jalan utama arah ke Kabupaten Boven Digoel. Pada awalnya, penulis lewat jalan darat menuju ke Muting, lanjut Asiki, lalu Tanah Merah. Menyimpang ke kanan, kemudian masuk ke wilayah Mandobo, terus ke Mindiptana, Ninati, dan Waropko. Pada waktu perjalanan ini dilaksanakan, wilayah kehidupan suku Muyu masuk ke Kabupaten Boven Digoel, Papua.

\footnotetext{
${ }^{4}$ Dr. Enny Kenangalem, MSc adalah dokter perempuan pertama dari wilayah pegunungan. Ia berasal dari Yahukimo. Lulus dari Fakultas Kedokteran Universitas Sam Ratulangi (Unsrat) Manado, saat ini ditempatkan di RSUD Timika. Wawancara dilakukan Juni 2018.
} 
Terdapat banyak sungai di wilayah ini. Yang besar adalah Sungai Digoel, yang memanjang mulai dari atas Distrik Waropko, terus turun ke Laut Arafura. Sungai Digoel ini bergabung dengan Sungai Kao, Sungai Muyu, dan Sungai Mappy. Di bagian paling timur Boven Digoel, ada Sungai Fly yang membatasi wilayah Muyu dengan Negeri Papua Nugini. Beberapa desa yang penulis catat dan kunjungi antara lain adalah di sebelah timur dan utara Sungai Digoel: Kanggewot, Kanggim, Kawangtet, Metemko, Mindiptana, Ninati, Tinimbit, Tumutu, Woman, Womabki, Waropko, dan Yibi. Arah sebelah barat Sungai Digoel adalah: Asiki, Mandobo, dan Tanah Merah, dan Getentiri.

Di zaman pemerintahan Belanda 1930 - 1936 - 1945, Muyu merupakan wilayah yang terpisah dari Boven Digoel. Boven Digoel ada di sebelah kanan Sungai Digoel, sementara Muyu ada di sebelah kiri sungai. Pada tahun 1932 misi dari wilayah Muting sekitar 60 km dari kota Merauke - menyusuri Sungai Digoel masuk ke Distrik Ninati. Pada waktu itu orang-orang Muyu masih tinggal di rumah tinggi. Waktu itu di Ninati hanya terdapat dua rumah saja. Selebihnya adalah hutan lebat. Misi mulai meratakan tanah, membuka kebun, dan membangun Bivak ${ }^{5}$ besar.

\footnotetext{
${ }^{5}$ Bivak adalah semacam "penginapan" di pedalaman, tempat orang tinggal untuk sementara.
} 


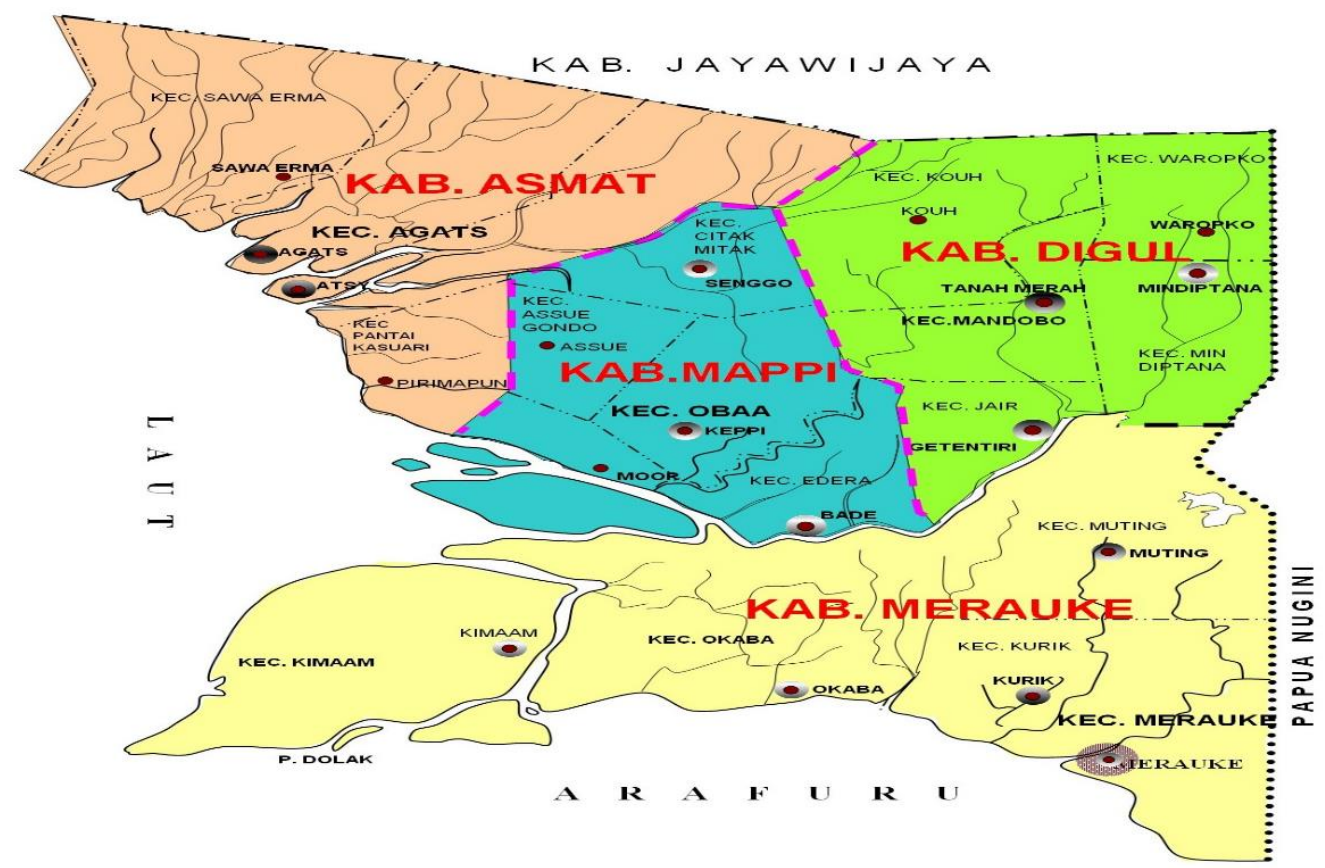

Sumber: Egrafis 2018

\section{Gambar 4. Peta Kota dan Kabupaten Merauke}

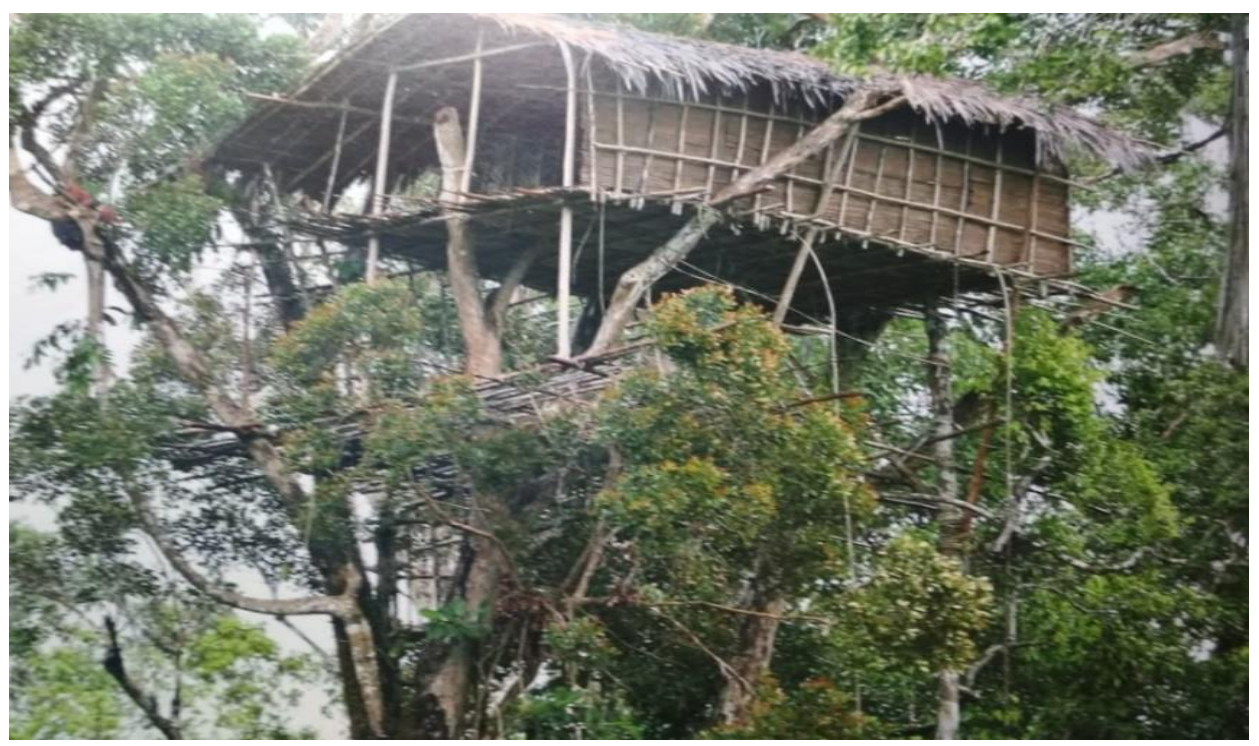

Sumber: Dokumentasi penulis

\section{Gambar 5. Rumah Adat Suku Muyu}




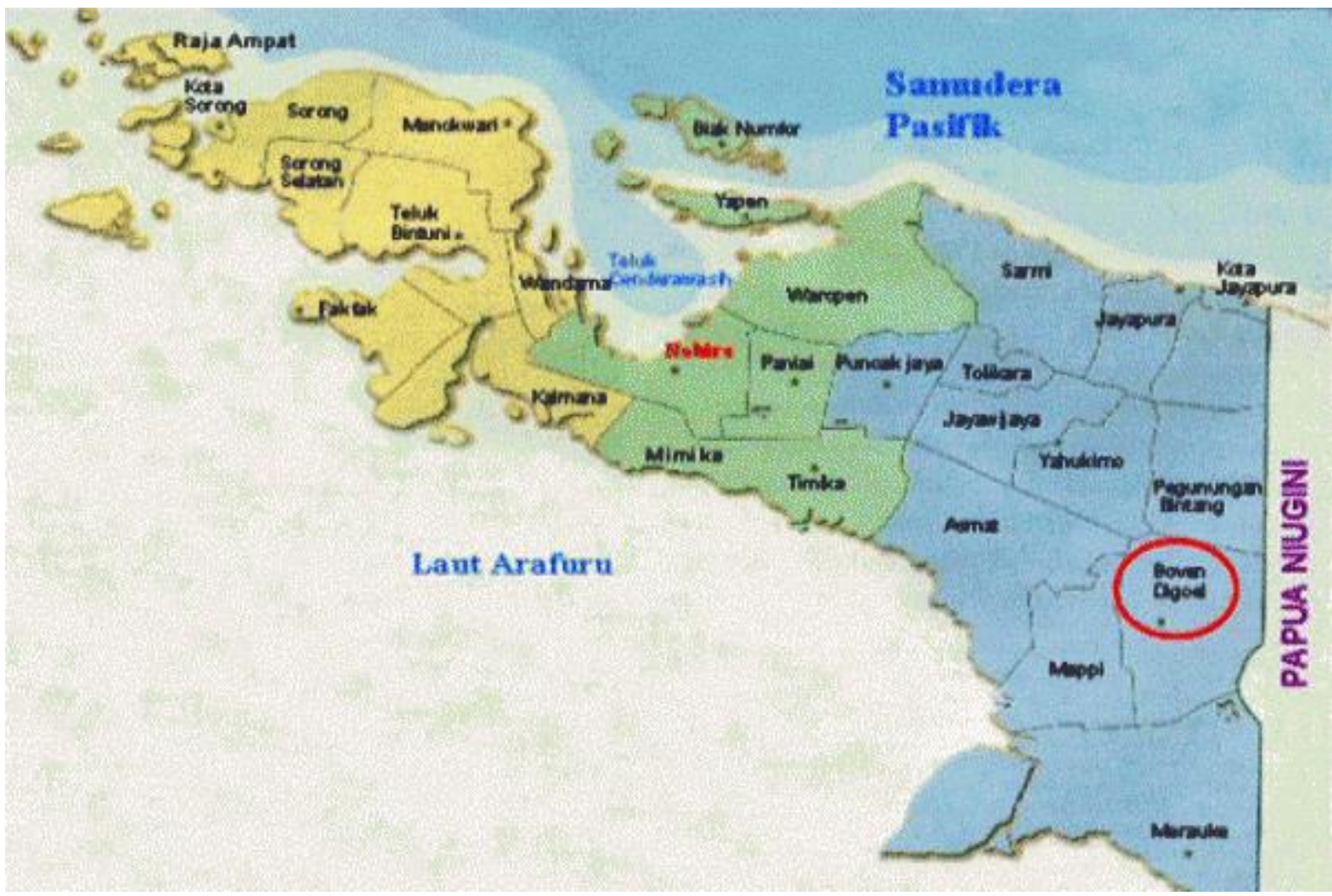

Sumber: Irwanto Info 2016

\section{Gambar 6. Peta Kabupaten Boven Digoel}

Daerah Muyu adalah daerah hutan basah dan lembab. Matahari tidak nampak karena tingginya pepohonan. Pada tahun 1933 sekolah dimulai di Ninati. Guru-guru didatangkan dari Kei - Maluku, dan tinggal di Bivak. Sekolah sederhana dimulai tahun 1933 di Ninati, Ogemkapa, Kamakbon, dan Jibi (Duivenvoorde 2000, 59). Selanjutnya berturut-turut gereja membuka sekolah pada tahun 1934 di Jononggo, Wambiran, Jomkondo, dan Nams; tahun 1937 di Kakuna, dan Metomka; tahun 1938 di Mindiptana dan Atko; tahun 1942 di Kimkawip, Minipko, Kawangtet, Kanggim, Jiptem, Imko, Angkamburan, Kanggup, dan Amburan; tahun 1943 di Mana, Kanggewot, Ninikapa, Kimki, dan Komera (Duivenvoorde 2000,60 ). Dengan cara yang mengagumkan, anak-anak sekolah itu belajar dalam bahasa Indonesia (Melayu). Gereja untuk pertama kalinya membaptis warga suku suku Muyu, yakni pada perayaan Natal tahun 1937, dengan jumlah 80 orang. 
Segala kegiatan pembangunan oleh gereja ini terhenti karena Jepang masuk pada tahun 1943. Kiriman guru tidak bisa lagi dilakukan, sehingga pekerja gereja 'memaksa' oarng Muyu (yang pandai dan menonjol) untuk mulai membantu mengajar. Pada tahuntahun awal karya gereja, mereka juga membangun rumah-rumah bagi penduduk. Tanpa uang, mereka memakai bahan lokal: tiang dari kayu, atap dari daun, lantai dari belahanbelahan nibung. Rumah-rumah dibangun berdekatan. Di tengah-tengah kampung berdiri gereja. Kehidupan individual, dan rasa saling curiga mulai dikurangi.

Saat penulis berkunjung, keadaan sudah berubah ${ }^{6}$. Ada listrik di jalan-jalan utama kota. Tetapi, fokus pembangunan bukan di Ninati, melainkan di Tanah Merah dan Asiki yang mulai mekar. Mindiptana yang dijadikan primadona daerah modern, sudah meredup. Suasana desa-desa juga sudah diwarnai oleh beberapa sepeda motor yang mulai berseliweran. Di kampung-kampung, ${ }^{7}$ rumah sudah bukan lagi "rumah tinggi", melainkan rumah datar, dengan pagar pepohonan. Di sana-sini nampak ayam berkeliaran.

Suku Muyu adalah petani-peternak sekaligus pedagang yang tangguh. Sebelum kehidupan modern tiba, orang-orang Muyu biasa mempertukarkan hasil kebun dan ternaknya dengan bayaran uang, berbentuk siput atau kerang kecil yang digosok, disebut Ot. ${ }^{8}$ Dengan uang yang diperoleh, mereka membayar mas kawin untuk mendapatkan isteri. Kaum perempuan mengerjakan kebun dan memelihara babi. Kaum laki-laki berburu dan berdagang. Pada kesempatan tertentu, ratusan orang Muyu berkumpul

\footnotetext{
${ }^{6}$ Awal pertama penulis berkunjung adalah tahun 2000 ke pinggiran Kabupaten Merauke. Kemudian berturut-turut berkenalan lebih intens dengan masyarakat Muyu warga desa Bupul dan Mindiptana, mulai tahun 2007 dst.

${ }^{7}$ Penulis kurang memperhatikan, apakah desa yang penulis kumjungi itu sebuah distrik, atau hanya sebuah desa. Secara administratif tidak penulis perhatikan.

${ }^{8}$ Sampai dengan tahun 1950-1960-an, uang Ot masih beredar.
} 
untuk membuka pasar, jual beli daging babi dan segala benda pekerjaan tangan atau hasil buruan.

Sifat yang menonjol dari suku ini adalah bertekad mandiri (lebih ke arah individual), menghargai kepandaiannya sendiri, bangga atas harta miliknya: babi, tanah, isteri, uang. Mencurigai siapa pun yang kurang dikenal. Sampai dalam perkawinan pun, antara suami-isteri kalau ada sesuatu yang merugikan, masing-masing harus membayar. Perdagangan dilakukan secara bersaing. Yang berhutang, bila berlambat-lambat membayar, diancam dibunuh secara fisik maupun dengan magis. Balas dendam memproduksi berderet perkara.

Tugas wanita - kebun dan babi - tidak berubah. Orang-orang Muyu cenderung menambah isteri, menjadi dua hingga tiga orang. Tetapi mereka yang sudah menjadi Kristen, menolak hal ini. Waktu keluarga memaksa-maksa, gadis-gadis ini melarikan diri ke gereja. Lalu kaum perempuan ini diterima untuk tinggal di asrama. Suasana langsung berubah. Perumahan suster yang damai dengan anak-anak sekolah, menjadi terancam. Kaum pria Muyu yang merasa dirugikan, mendatangi gereja dengan busur dan panah. Kaum bapak menuduh anak-anak perempuan itu memberontak dan tidak taat. Selang beberapa waktu, diputuskan untuk memindahkan para gadis ini ke Merauke dan keadaan menjadi aman.

Misionaris perempuan memperkenalkan kepada generasi muda masalah kesehatan, keterampilan - memasak, menjahit - dan mengelola rumah tangga. Para misionaris juga membangun jam-jam doa, suatu hal yang sebelumnya tidak dikenal oleh masyarakat. Wilayah Muyu tahap demi tahap berkembang dengan bantuan para misionaris.

Kebun-kebun dibuka demi meningkatkan kehidupan rakyat. Awalnya kebun coklat, kemudian karet. Gedung-gedung pemerintah mulai dibangun. Lapangan kerja 
dibuka. Mindiptana menjadi kota kecil, ramai dan penuh kegiatan. Ini mengurangi arus keberangkatan generasi muda yang mencari kerja di Sorong, Merauke, dan Jayapura. Jalan pertama dibangun, menghubungkan Mindiptana dengan Waropko dan Ninati. Langsung keadaan ini mengubah orang Muyu menjadi pribadi yang lebih terbuka. Mereka menjadi orang yang energik, pandai dan tekun, dan haus belajar. Pada tahun 1970-an, para pemuda Muyu mulai dikirim ke luar. Mereka menempuh pelajaran sekolah menengah di Merauke. Dari sini, para pemuda yang terpilih dikirim ke Pulau Jawa untuk menempuh pendidikan tinggi. ${ }^{9}$

Peran perempuan di kebudayaan Muyu bisa dicatat secara khusus di sini. Memang benar mereka cerdas, tekun, sangat energik, dan menjadi perempuan yang mandiri secara ekonomi. Akan tetapi di tengah adat, mereka dirugikan. Adat yang umum melandasi orang Muyu adalah bahwa mereka sangat percaya pada diri sendiri, mudah iri terhadap orang lain, cenderung membela diri sampai bersedia membunuh. Akan tetapi dalam diri manusia yang sama ini juga terdapat sikap yang lain. Dalam lubuk hati yang terdalam, mereka rindu untuk ikut berpartisipasi, menikmati damai dalam hubungan yang akrab. Kedua hal itu masih sulit bertemu dalam hidup yang konkrit. Kesulitan terutama dirasakan oleh kaum perempuan. Kesulitan-kesulitan itu antara lain adalah:

- Dalam hal sistem perkawinan

Basis dalam sistem perkawinan Muyu adalah "Tukon" (bride-price). Institusi "Tukon" ini memberi kemungkinan untuk mengadakan pertukaran perempuan secara tidak langsung. "Tukon" terdiri dari barang-barang yang memiliki fungsi tertentu dalam kehidupan sesehari orang Muyu. Barang-barang itu juga tak harus memiliki nilai

\footnotetext{
${ }^{9}$ Satu orang pemuda Muyu dikirim ke Bandung, kurang beruntung. Lalu dipindah dan masuk ke Fakultas Kedokteran UKI di Jakarta. Pemuda ini berhasil menjadi seorang dokter. Menjadi Kepala Dinas Kesehatan di Merauke tahun 2000-an. Saat ini, ia menjabat Sekretaris Satu di Kabupaten Boven Digoel. Namanya adalah dr. Titus Tambaip, M.Kes. Bukan itu saja, anak dokter Titus, adalah juga seorang dokter yang lulus dari Fakultas Kedokteran Universitas Guang Zhou di China (2015).
} 
tradisional yang murni. Barang-barang itu bisa disebut, misalnya: 'ot' - sejenis uang dari kerang Kauri yang digosok halus, 'inam' - hiasan jidat dari kerang kecil-kecil yang dijahit rapi, 'wam' - kerang putih yang besar dan pipih, sebagai kalung menggantung di dada laki-laki atau di punggung belakang, 'yirip' - untaian gigi anjing, yang diselingi dengan gigi taring yang besar. Pada pesta, para lelaki memakainya sebagai hiasan di paha untuk menyangga koteka, 'tamat' - kapak batu, 'tabukyot' - gulungan tembakau, tanaman sendiri, 'mindit' - gigi anjing dalam bentuk untaian rantai.

Dengan dibayarnya "Tukon", maka kepemilikan perempuan itu (nantinya akan menjadi isteri), beralih sepenuhnya kepada si pria (nantinya akan menjadi suami). Perempuan tidak punya hak menggugat perceraian. "Tukon" sudah mengalihkan hak itu kepada laki-laki, bahkan pun bila ia diperlakukan kasar, ia tidak boleh pulang atau lari. Bisa terjadi seorang suami membunuh isterinya karena suatu ketidak-puasan atau kemarahan. Tetapi keluarga tidak akan mengambil tindakan apapun karena isteri itu sudah dibeli.

- Perkawinan Poligami

Institusi "Tukon" juga memungkinkan terjadinya poligami. Orang yang sanggup membayar "'Tukon" (ber-ulang-ulang) akan memungkinkannya memiliki banyak istri. Perkawinan poligami selain karena motif seksual, bisa juga karena alasan ekonomi. Perempuan memegang banyak tugas dalam rumah tangga Muyu. Ia menggarap kebun, membersihkannya, mengumpulkan hasilnya, dan menyajikannya dalam masakan keluarga. Selain itu ia juga menokok sagu, mengurus babi, mencari kayu bakar, dan mengasuh anak-anak, mulai dari yang bayi, sampai dengan mereka yang masih berumur tiga sampai enam tahun. Belum lagi bila ia sedang hamil. Dengan cara institusi "Tukon" ini, kaum perempuan bisa dikawini oleh laki-laki tua, atau menjadi isteri kedua, dan tak mampu melawan. Kekasih yang dicintainya tak selalu bisa menikahinya apabila diketahui 
bahwa ia tak sanggup menyediakan "Tukon" seperti yang diminta oleh keluarga perempuan.

Suku Muyu mempunyai kepercayaan khusus bahwa ada kuasa pada "babi keramat" (Kamberop). Babi keramat ini menanggung dua fungsi: untuk mensukseskan 'Pesta Babi', dan untuk menolak penyakit. Babi di sini bertindak sebagai medium. Kaum perempuan dan anak-anak dilarang menghadiri penyembelihan babi ini, juga dilarang ikut memakan dagingnya. Sebab perempuan bisa dipakai sebagai medium oleh arwah (benep) yang jahat.

Perempuan yang sedang haid juga dianggap pembawa bencana. Dia bisa menyebabkan perburuan gagal, atau panen tidak seperti yang diharapkan. Jadi, ketika dia sedang haid, dia harus ke luar dari rumah suaminya. Kembali masuk rumah bila haid sudah selesai. Perempuan ini juga dilarang berada di tempat umum sebab dia membawa sial.

Bila terjadi kematian, kewajiban perempuanlah untuk terus meratapi jenazah, sampai jenazah itu dibawa ke kubur. Meratap dengan suara berteriak-teriak ini sungguh melelahkan perempuan. Bila keluarga dekat meninggal, perempuan wajib melakukan tinggimini, yakni memotong dua ruas jari telunjuk dan jari tengahnya dari tangan sebelah kanan sebagai tanda dukacita yang mendalam. Ini dianggap sebagai tindakan mengikat arwah si mati. Roh arwah itu akan memberitahunya bila ada bahaya mengancam atau pencurian. Tempat bekas jari terpotong itu akan berdenyut (Schoorl 1997, 185-189).

Dalam upacara inisiasi, makanan yang dimasak oleh perempuan tidak boleh disantap. Pelanggaran terhadap aturan ini akan mengakibatkan penyakit pada si peserta, yakni radang pada kemaluan, atau mendapat luka, atau mengalami demam. Kepercayaan Muyu akan pengaruh arwah orang mati, membuat perempuan juga dianggap 'berbahaya' 
karena bisa menjadi sasaran pembalasan. ${ }^{10}$ Perempuan juga dilarang makan daging babi dan kasuari - hasil buruan pemuda yang belum kawin. Perempuan dianggap bisa menyedot "kesaktian" si pemburu.

Menjadi nyata sekarang, bahwa gerak perempuan lebih terbatas dibandingkan gerak laki-laki. Di kehidupan nyata sehari-hari, perempuan Muyu yang sudah menikah nampak "menjauh" dari kegiatan laki-laki. Bahkan pun dengan suaminya, mereka tidak nampak akrab.

Sebuah pemandangan di Pasar Baru Digoel, memperlihatkan gambaran di atas. ${ }^{11}$ Hampir seluruh pasar itu dipenuhi oleh pedagang perempuan, orang Muyu lebih banyak ketimbang orang Mandobo. Mereka menggelar dagangannya dengan rapi, dan menungguinya dengan tetap melakukan kegiatan lain seperti merajut noken atau mengiris-iris sesuatu. Hilir mudik kaum perempuan mengangkati barang-barang jualannya, tidak ditolong oleh laki-laki. Mereka mengurus barang-barang jualannya itu mulai dari kebun, mencucinya di sungai, memotong bagian-bagian yang tidak bagus, mengikatnya dalam untaian-untaian supaya mudah diberi harga, dan menggendongnya dengan berjalan sampai ke pasar. Anak-anak kecil banyak yang mengikuti ibunya berjualan di pasar.

\section{- Pendidikan dan Public Figure}

Perempuan Muyu terlalu sibuk di kehidupan sesehari, hingga kurang nampak di level menengah ke atas. Penulis mengenal satu orang Muyu yang menjadi anggota DPR-D Kabupaten Merauke di tahun 2001, yang dikenal aktif sebagai aktivis perempuan. Pada periode itu, bupati Merauke adalah John Gluba Gebze, seorang "warrior" dari suku

\footnotetext{
${ }^{10}$ Dalam kepercayaan Muyu, setiap kali orang meninggal, selalu dicari penyebabnya. Mungkin ada musuh yang membunuhnya lewat sihir atau mengirim arwah untuk membunuhnya.

${ }^{11}$ Penulis mengunjungi Pasar Baru di Tanah Merah, Boven Digoel pada bulan Juni 2014.
} 
Marind. Sesudah masa 2001-2006 itu, kepemimpinan Bupati Boven Digoel Yusak Yaluwo - di mana teritori adat suku Muyu ada di wilayahnya - kurang memberikan semangat bagi munculnya perempuan Muyu.

Di perguruan tinggi, perempuan Muyu nampak kurang agresif dibanding perempuan-perempuan dari suku Asmat maupun Mappy. Anak-anak laki Muyu nampak lebih menonjol, dibanding anak-anak perempuan. ${ }^{12}$ Sebaliknya, di perkumpulan kaum ibu, mama-mama Muyu nampak lebih aktif membuka diri dengan menceritakan kisah hidupnya dibanding mama-mama dari Marind atau Mandobo. Mama-mama Marind hanya nampak 'heboh' saja, namun tidak pandai menyusun kisah dalam kalimat-kalimat yang naratif. 13

Dari 300 orang yang mendaftar, hanya dua orang laki-laki. Pelayanan ini berjudul "lansia" - lanjut usia, namun di dalamnya bergabung kaum perempuan dari usia 40-an sampai dengan 84 tahun. ${ }^{14}$ Karena ini ada di kota Merauke, maka peserta terbanyak yang bergabung adalah perempuan suku Muyu, Marind, dan beberapa Mandobo. Sisanya berasal dari suku Asmat, Mappy, Flores, Jawa, Manado, Ambon, dan Toraja. Mereka yang sudah tua, atau yang tinggal jauh - lebih dari 6-7 km dari Polder - dijemput dengan mobil, dan pulang juga diantar.

Sembilan puluh persen anggota komunitas penulis datang dari masyarakat bawah yang kurang berpendidikan dan tersingkir-terabaikan. Delapan puluh persen dari anggota adalah janda atau ditinggal suami untuk kawin lagi. Dua puluh persen sisanya adalah adalah perempuan yang masih bersuami, tapi tidak dinafkahi, dan umumnya

\footnotetext{
12 Pada tahun 2006 penulis bersama kawan-kawan mendirikan sebuah perguruan tinggi bernama STISIPOL Yaleka Maro Merauke dengan tiga Fakultas: Fakultas Ekonomi, Ilmu Pemerintahan, dan Administrasi Publik.

${ }^{13}$ Tahun 2007-2009 penulis mendirikan sebuah pelayanan lansia di wilayah Polder - Merauke, dengan nama Komunitas Lentera, di bawah naungan Yayasan Lentera Kasih.

${ }^{14}$ Tertua bernama Mama Atek, perempuan Muyu, berusia 84 tahun. Beliau rajin datang, tapi hanya bertahan tiga tahun dan meninggal dunia.
} 
mengalami kekerasan dalam rumah tangga (KDRT). Bahkan tak jarang mereka mengalami kekerasan dari pihak cucu. Terkadang mereka datang ke lokasi kami berkumpul dalam keadaan yang sangat menyedihkan: menangis, lapar, sakit, atau berluka (kejatuhan kelapa, kena parang, kaki kena pacul, jari teriris pisau, atau berkelahi dengan orang mabuk yang mencoba memperkosa mereka). Anak-anak mereka lapar, atau tidak ke sekolah karena tidak ada uang untuk transportasi, dan lain-lain.

- Apa yang Bisa Dikerjakan

Pelayanan ini sebetulnya ingin mengumpulkan semua orang tua di Merauke. Tapi dalam kenyataannya, Komunitas Lentera melayani mereka yang 'neglected', yang 'tak terurus', baik oleh keluarga maupun oleh pemerintah. Keluarga tidak megurus mereka, karena keterbatasan yang ada: kemiskinan, rumah yang sempit, waktu yang habis untuk kerja kebun, pendidikan yang terbatas, dll. Karena anak-anak melawan dan tidak tunduk dan penurut, makanan yang terbatas, lahan yang sempit, dan kondisi lainnya, membuat pikiran kusut dan kesehatan menurun. Belum lagi perkelahian dengan suami, bagi mereka yang masih memiliki pasangan. Jadilah lokasi pelayanan kami ini menjadi semacam 'tempat penghiburan' dan 'tempat melepas sesak dada'.

Dengan kekuatan seadanya, kami melayani para mama ini dua kali seminggu, Kamis dan Sabtu. Pada hari Kamis, tim bergerak hampir seharian. Dua orang dari kami dengan dua mobil - satu mobil Station Wagon, satu mobil kuda Mitzubishi Tiga Berlian bergerak mengelilingi jalanan sampai ke pinggiran kota - menjemputi kaum perempuan renta itu. Mereka sudah menyemut di pinggir-pinggir jalan di spot-spot tertentu menunggu mobil petugas penjemputan yang dimulai pukul delapan sampai dengan pukul sembilan pagi. Setelah tiba, mereka dituntun untuk duduk dan diberi air minum dan kue. Musik dimainkan oleh seorang kawan. Berdiri seorang master of ceremony (MC) dan mulai menyapa dengan ramah, “Apa kabar? Sehat? Harap ada sukacita!”, dst. Lalu 
segera menyanyikan beberapa lagu pujian, dan membuka pertemuan dengan doa; minta Tuhan menyertai kami dengan Roh Sukacita yang dari surga. Setelah itu, segera datang kawan lain, mengajak mama-mama berdiri, menyanyi, berdansa, dan bermain; berputar, ganti pasangan, dan lain-lain. Semua bergembira.

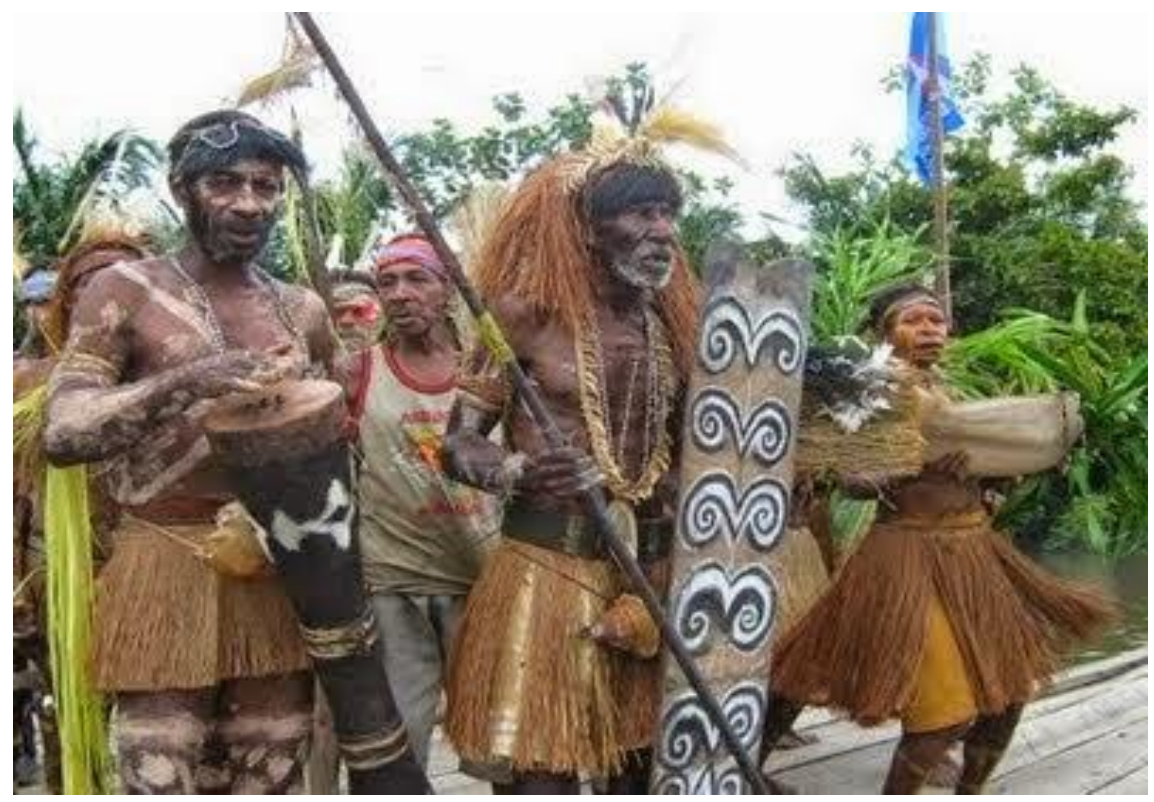

Sumber: Dokumentasi penulis

\section{Gambar 7. Suku Muyu}

Sekitar empat puluh menit kemudian, musik menjadi lembut dan mama-mama diminta duduk. Lalu MC tadi minta mama-mama bersaksi, memberi testimoni tentang apa yang terjadi dalam hidup mereka selama seminggu yang lalu. Di sini mereka menceritakan kesusahan, kesehatan, KDRT, dan lainnya yang menimpa mereka. Umumnya mereka menangis di sesi ini. Ini memakan waktu banyak, hampir satu setengah jam atau terkadang lebih - sebab inilah inti pertemuan, sebuah rekayasa mengobati dan menyembuhkan (curing and healing).

Keadaan menjadi senyap terbawa perasaan sedih karena mendengar kesaksian kawan-kawan peserta. Kemudian tampil seorang pendeta atau pelayan Firman, bicara tentang kasih penyertaan Tuhan. Sesudah itu semua yang tadi diperdengarkan, dibawa dalam doa. Musik dimainkan, dan lagu-lagu penutup dilantunkan bersama. Pertemuan 
ditutup dengan makan bersama. Jam sudah menunjukkan pukul dua atau tiga sore. Kawan yang bertugas mengantar mereka pulang. Mereka pulang dengan membawa kantongan: gula dan beras, atau supermi, atau beberapa makanan seperti ubi dan pisang goreng. Hari Kamis selesai.

Hari Jumat malam, pukul 20.00 hingga 01.00 pagi adalah hari doa semalaman. Acara ini dihadiri oleh mereka yang sehat saja. Biasanya peserta sekitar 20-25 orang. Ini adalah acara sharing tentang persoalan keluarga dan persoalan pemerintah. Apa yang terjadi dan apa yang harus dibuat. Kami melantunkan lagu-lagu penyembahan, sharing, dan berdoa bergantian. Pukul 01.00 pagi kami tidur. Pukul 06.00 pagi kami pulang. Pada acara "Doa Semaleman" ini, tidak ada makan malam. Yang terhidang adalah kue-kue, kopi, dan teh.

Sebulan sekali, tepatnya setiap Selasa minggu kedua, kami melakukan pemeriksaan kesehatan. Dokter kepala Puskesmas dan dua-tiga orang petugas dari Dinas Kesehatan kami undang untuk melakukan pemeriksaan atas mama-mama yang tergabung di Komunitas Lentera ini. Satu per satu ditimbang badannya, dicatat tekanan darahnya, dan diberi obat/vitamin bagi yang dirasa perlu. Beberapa yang sakit serius, seperti jantung, TBC, diabetes, dll., dirujuk ke RS Pemda untuk ditangani lebih lanjut. Mama-mama ini memiliki catatan kartu kesehatan khusus lansia. Semuanya diberikan gratis, tanpa uang satu sen pun. Pada kesempatan-kesempatan tertentu, juga dilakukan pemeriksaan mata dan operasi katarak. Kegiatan ini bekerja sama dengan pelayanan misi gereja. Dokter didatangkan dari Jayapura. Pemeriksaan ini juga gratis. Hanya untuk pemasangan kacamata, peserta diminta mengganti harga "frame"-nya. Untuk yang terakhir ini banyak yang tidak sanggup membayar. ${ }^{15}$

\footnotetext{
15 Ini dilakukan pada tahun 2007, dengan bantuan RS Misi, yakni RS Kasih Bunda Jalan Misi, Merauke.
} 
Apakah yang dilakukan Pemerintah Daerah waktu itu? Tidak ada! Tapi ada yang perlu dicatat: bupati Merauke waktu itu, Bapak John Gluba Gebze, mengunjungi lokasi kami, bertemu dan menyapa mama-mama ini, dan menyatakan bahwa minggu depan yakni hari Natal tahun 2008 - akan diberikan hadiah buat mama-mama ini. Ini adalah hadiah pribadi dari beliau, yakni disembelih lima ekor sapi, sehingga masing-masing mama membawa pulang tiga kilogram daging. ${ }^{16}$ Selain itu ada bingkisan untuk setiap mama, yakni sebuah kantongan dengan isi: susu kental manis, kopi, gula, teh, sarden, dan Maling17. Bupati Gebze memang memiliki sebuah peternakan.

Dalam pelayanan yang penulis sempat memimpinnya selama tiga tahun-diselingi dengan pulang ke Jakarta-nyata terlihat bahwa dalam lingkungan baru ini masalahmasalah adat bisa dilupakan, atau lebih tepat tidak menjadi gangguan dalam pikiran. Masalah dendam, iri hati, ketakutan kepada sihir, dan lain-lain berhasil disingkirkan. Semua mama diminta mendengarkan Firman dan berdoa dengan lebih intens.

\section{Penutup: Pemberdayaan yang Penting}

Tugas negara, seperti yang telah diungkapkan di awal tadi, adalah melaksanakan UndangUndang Dasar yang merupakan alasan utama bernegara. Antara lain tugas itu adalah: menjamin terlaksananya hak dan kewajiban rakyat di seluruh wilayah kedaulatannya, termasuk kaum perempuan. Apa sajakah itu?

Dalam uraian sebelumnya, penulis telah menunjukkan terdapat problematika sosiologis dalam masalah perempuan, baik dari suku Kamoro maupun suku Muyu.

\footnotetext{
16 Sangat heboh pada waktu itu, di mana dua truk besar memasuki pekarangan lokasi kami, membawa daging dan semua oleh-oleh bupati buat kaum papa perempuan. Banyak rakyat datang menonton. Tiga ratus anggota Komunitas Lentera menikmati daging sapi segar untuk ber-Natal. Bisa dibayangkan betapa repotnya petugas jagal menimbang dan memasukkan potongan-potongan daging itu ke dalam plastik khusus. Tangan mereka pastilah pegal!

17 Sebuah merek daging babi kemasan yang diimpor dari Republik Rakyat Tiongkok.
} 
Seperti kita tahu, posisi perempuan dan laki-laki ditentukan oleh sistem seks atau gender yang dihidupi oleh masyarakat itu. Menurut pikiran Nicola Lacey (1996) tentang perempuan dan hukum, disebutkan bahwa sistem pembagian jenis kelamin (seks) yang berlaku di masyarakat menentukan substansi hukum. Sistem ini berkelindan, atau saling tumpang tindah bercampuran seperti rambut yang dikepang, dengan isu gender. Jenis kelamin berhubungan dengan karakter biologis, tetapi gender berkaitan dengan karakter sosial budaya. Karakter sosial-budaya ini memengaruhi sistem masyarakat. Jika karakter biologis sulit diubah, maka gender memiliki kemungkinan untuk berubah dan berkembang. Potensi berubah ini yang menyebabkan gender menjadi elemen penting dalam kebijakan-kebijakan atau dalam perumusan-perumusan peraturan dan hukum.

Dalam banyak kasus ada beberapa alasan mengapa perlu memasukkan perempuan dalam perspektif hukum. Hal itu antara lain dalam hal property keluarga, khususnya pembagian harta benda perkawinan (harta bersama) yang berdasarkan ketentuan harus dibagi dua berdasarkan prinsip kesetaraan. Di bidang kesehatan, perempuan sungguh berhak menerima perlakuan khusus bila sedang hamil atau melahirkan. Tapi sistem "kapitalistik" membuat beban kemiskinan yang ada di masyarakat berada di bahu perempuan. Demikian juga dengan sistem patriarki yang merupakan pemahaman laki-laki di mana perempuan wajar didominasi (Santoso 2014, 43-47).

Beban yang berat di pundak perempuan menyebabkan perempuan tidak punya waktu untuk meningkatkan diri. Kalau ruang untuk perempuan itu terbatas, maka hal ini akan menyebabkan rendahnya partisipasi perempuan dalam pembangunan bangsa. Generasi muda yang adalah tanggung-jawab perempuan untuk melahirkannya, akan tidak maksimal bertumbuh dan berkembang. Sementara itu, adalah di pundak perempuan sebuah bangsa bersandar. Perempuanlah yang melahirkan suatu bangsa. 
Karena itu, sudah selayaknya perempuan diberi keleluasaan untuk bertumbuh dan berkembang-juga bagi para perempuan Papua. Negara dengan kedaulatannya wajib menuntaskan problematika sosiologis dalam perumusan kebijakan-kebijakannya. Problematika yang sering muncul, seperti yang terungkap dalam kunjungan-kunjungan penulis, adalah masalah keluarga/internal yang begitu hebat merusak sehingga menjadi masalah sosial. Problematika sosial yang tuntas akan dapat menjamin partisipasi setiap warga negara tanpa terkecuali.

\section{Referensi}

Bentara Budaya, Freeport, dan Papua Center Universitas Indonesia. 2012. Kamoro: Tinggalan Budaya "Maramowe". Timika: Freeport.

Duivenvoorde, Jacobus. 2000. Sejarah Gereja Katolik di Irian Selatan. Merauke: Keuskupan Agung Merauke.

Egrafis. 2018. “Merauke Kota Rusa: Mengenal Kabupaten Merauke.” Egrafis.com, 14 Januari. Diakses pada 18 Juni 2018. http://www.egrafis.com/gambar/meraukekota-rusa-mengenal-kabupaten-merauke

Irwanto Info. 2016. "Gambaran Umum Kabupaten Boven Digoel." Irwanto.info, 20 Mei. Diakses 18 Juni 2018. http://irwanto.info/wp-content/uploads/2016/05/PETAKABUPATEN-BOVEN-DIGOEL.gif

Lacey, Nicola. 1996. Feminism and Conventional Legal Theory. Berlin: Humboldt Forum Recht.

Muller, Kal. 2016. Kamoro: The Mimika Tribe. Timika: Yayasan Maramowe Waeiku Kamorowe bekerja sama dengan PT Freeport Indonesia.

Pemerintah Daerah Kabupaten Mimika. Tanpa tanggal. Mimikakab.go.id. Diakses pada $\underline{18}$ Juni 2018. http://www.mimikakab.go.id

Pouwer, Jan. 2010. Gender, Ritual and Social Formation in West Papua: A Configurational Analysis Comparing Asmat and Kamoro. Leiden: KITVL Press.

Santoso, Wijayanti. 2014. Perempuan dan Hak Asasi Manusia. Jakarta: LIPI dan PT Gading Inti Prima.

Schoorl, J. W. 1997. Culture and Change Among the Muyu. Leiden, the Netherlands: Royal Institute of Linguistics and Anthropology.

World Team Papua. 2009. "Current maps of Papua." Diakses 28 Januari 2019. http://www.worldteampapua.org/media/maps/current/pmap large.jpg 
